\title{
Making Education Law Meaningful to Beginning Teachers: A Narrative Inquiry
}

\author{
Julian Kitchen \\ Brock University
}

\begin{abstract}
Teacher education classes are contested spaces. Professors interested in reforming content, pedagogy and assessment must wrestle with their own internal tensions and the culture of their institutions in order to make a difference. In this paper, a teacher educator uses narrative inquiry to frame his efforts to become a constructivist professor of education law. Critical tensions are examined using a three-dimensional narrative inquiry space: looking inward, outward, backward, and forward. Critical reflections, written over several years, are used to situate the tensions experienced in this case into the broader context of the author's career journey.
\end{abstract}

Keywords: teacher education; reform; narrative inquiry; constructivist; education law 


\section{Making Education Law Meaningful to Beginning Teachers: A Narrative Inquiry}

Teacher education classrooms are contested spaces in which the decisions educators regarding content, pedagogy, and assessment have ethical dimensions and implications (Kincheloe, 2008). Traditionally, knowledge for teachers (Connelly \& Clandinin , 2000) - the formal curriculumretains primacy over teacher knowledge (Connelly \& Clandinin, 2000)-the curriculum of lives as lived by teachers in relation to students in schools (Downey \& Clandinin, 2010).

During my 7 years at the University of Toronto, I was able to attend to teachers' personal practical knowledge (Connelly \& Clandinin, 1988) through narrative and reflective approaches in the core course in the teacher education program (e.g., Kitchen, 2005a; 2005b; 2008). I was also able to help teacher candidates consider the curriculum of lives in schools through action research (Kitchen \& Stevens, 2008) and school-based inquiry (Kitchen, Smyth, Thompson \& Lemoire, 2007). While I wrestled with the challenges of meeting a demanding course curriculum, I also felt I was generally able to "educate for an understanding of the narrative context, an attitude of inquiry, and a habit of 'getting to the bottom of things"' (Phillion \& Connelly, 2004, p. 468).

After I accepted a tenure-track position at Brock University in 2006, I wrestled with these tensions again as I confronted the challenge of teaching a 20-hour course on professionalism and law — with a rigorous curriculum that included numerous statutes, regulations, and legal casesin a manner that reflected my respect for teachers as curriculum-makers (Clandinin \& Connelly, 1992) and the lives of teachers and students on the educational landscape (Clandinin \& Connelly, 1995). In my journal at the end of the first year, I wrote:

Although the education law course went well, it was my one source of tension in a wonderful year.

In the first term, I followed the course outline closely.... I spent a considerable time translating complex legal cases into language students could understand. I also tried to work in a number of case studies, although this was difficult given the time it took to 'cover' the material.

When I collected interim feedback after four weeks, I was pleased with students' response. They found the lessons helpful, even though they would have preferred less lecturing. They particularly liked the time devoted to case studies... Their perspectives gave me permission to use more case studies and feed into my doubt about using a textbook targeted at lawyers and senior educational administrators.

For the sake of consistency and teamwork, little was changed when I taught the course again in the second term. I had changed, however, and experienced considerable cognitive dissonance as the pedagogy and assessment were not consistent with my philosophy and pedagogy of teacher education. (J. Kitchen, personal communication, June 1, 2007)

In this narrative inquiry, I draw on my experiences to puzzle over the challenges of making education law meaningful in the lives lived by teachers in schools. 


\section{Narrative Inquiry as Methodology and Way of Thinking}

Narrative is the phenomenon under study and narrative inquiry is "first and foremost a way of thinking about experience” (Connelly \& Clandinin , 2006, p. 477). Narrative inquiry emerged as a response to the technical rational assumption that research knowledge can be applied to practical problems with little reference to people or context (Schwab, 1970). Drawing on John Dewey's (1938) view that educative experiences that lead to growth emerge when teachers are responsive to "the situations in which interaction takes place" (p. 45), narrative inquiry explores how individual practitioners can make sense of the "complexity, uncertainty, instability, uniqueness and value-conflict” (p. 39) within a particular professional situation. Connelly and Clandinin (1988) stress the importance of knowing oneself in order to understand and effectively teach students in classrooms. Because narrative inquiry is the study of how people make meaning from experience, educators are encouraged to draw meaning from their own experiences as learners in order to adapt their practices to the needs of students and communities.

Narrative inquiry is more than "the study of stories or narratives or descriptions of a series of events" (Pinnegar \& Daynes, 2007, p. 4). It is “a multi-dimensional exploration of experience involving temporality (past, present, and future), interaction (personal and social), and location (place)" (Clandinin \& Connelly, 2004, p. 576). It involves the study of experience as story and, in particular, how people shape their lives through the stories they tell and how they interpret their past through stories. Narrative inquirers immerse themselves in experience as lived and told in stories, including their own stories "in an inquiry relationship with participants' lives" (Connelly \& Clandinin, 2006, p. 480). By engaging in narrative inquiry, teacher educators can enhance our understanding of ourselves as teacher educators, our contexts and practices. Understanding ourselves is a crucial step towards improving our practices and better serving the students in our classrooms (Clandinin \& Connelly, 2004). Appreciation of narrative inquiry as a methodology and a means of interpreting phenomena can lead to deeper understandings of teacher education practices.

In this three-dimensional narrative inquiry space, the phenomenon under study is my experience teaching education law. By composing "a text that at once looks backward and forward, looks inward and outward, and situates the experiences within place” (Clandinin \& Connelly, 2000, p. 140), I puzzle over the tensions I experienced and the broader tensions inherent in delivery of an education law curriculum. Inquiring critically into my narrative of experience, I draw on my reflective journal, course materials, and written feedback from students.

I begin by looking inward to the development of my personal practical knowledge (Connelly \& Clandinin, 1988) as a teacher and teacher educator. I then look backward to my 7 years as an adjunct professor, when I taught a general methods course and coordinated cohorts of teacher candidates. I reflect on the general methodology course I had designed which emphasized personal narratives, reflective practice, action research, and field-based experiences.

I look outward in order to situate my work and the experiences of preservice teachers in the larger educational context. In doing so, I situate the teaching of education law in the larger context of my work as a professor. I also reflect on how understanding education law can provide new teachers with authentic preparation for the realities of teaching. I then look forward to ways in which I am adapting my practice in order to become a more constructivist education law professor. In particular, I examine my efforts to develop a new education law textbook based 
on constructivist and narrative understandings of what it means to be an ethical and professional teacher.

By inquiring into experience through story, I seek to re-imagine and recreate ways of being a professor of education law within a plotline of lives (Clandinin, et al., 2006).

\section{Looking Inward at My Personal Practical Knowledge}

Education law can be a very dry subject. I vaguely recall studying law as part of my Bachelor of Education program over twenty years ago: dull lectures, laws decontextualized from experience, and excerpts from the Education Act to be memorized for the final examination. Worse, this information did little to prepare me for the ethical and legal dimensions of teaching. For example, in my first year of teaching, a girl sprained her ankle during soccer practice. The next morning, I casually mentioned this to the vice-principal. Until then, I had no idea that I needed to complete an incident report and failed to realize that an injury could lead to a negligence lawsuit. Fortunately, I was able to avoid ethical and legal problems due to a combination of good sense and good luck. (J. Kitchen, personal communication, November 13, 2006)

When I was an adjunct professor at University of Toronto, there was an education law module in the Teacher Education Seminar course I taught. The legal dimension, I increasingly came to realize, needed to be linked to a conception of teachers as caring professionals. When I made a presentation as part of my interview process at Brock, I focussed on developing an ethic of care through the teaching of professionalism and law. Later, as I prepared to teach the education law course, I conceptualized my classes as engaging and contextually meaningful.

Once I was hired, the challenge was to teach education law in a manner consistent with my constructivist and relational paradigm of teacher education while meeting rigorous curriculum expectations that seemed to emerge from a technical-rational paradigm.

My philosophy of teacher education is constructivist, relational, and grounded in an understanding that "education is development from within" (Dewey, 1938, p. 17), and a belief that teacher educators play a crucial role in fostering "experiences that lead to growth" (Dewey, 1938, p. 40) for teacher candidates. As a teacher educator, I am sensitive to the role that each participant plays as teacher and learner in the relationship, the milieus in which each lives and works; it stresses the need to present one's authentic self in relationships which are open, nonjudgmental and trusting. Fundamental to such an approach is respect for teacher candidates as practitioners who draw upon their personal practical knowledge to inform their classroom practice and who recognize that "knowing through relationship to self and others is central to teaching” (Hollingsworth, Dybdahl \& Minarik, 1993, p. 8).

This understanding, which emerged from my study of teacher experiences and my narrative inquiry into the experiences of a classroom teacher (Kitchen, 2009), led me to question existing approaches to teacher education. I wrote:

When I became a teacher educator I recognized that I was assuming a significant level of responsibility for the personal professional development of others. My tension was heightened both by my perception that the prevailing approach to teacher education did not draw on the personal 
professional knowledge of preservice teachers and my concern that I lacked the professional expertise needed to teach at the university level. I looked inward and backward to my experiences as a preservice teacher and mentor teacher to situate myself as a relational teacher educator. (Kitchen, 2005a, p.

19)

As a relational teacher educator, I sought to help students construct their own meaning as curriculum makers. Dominice (2000) writes "each adult learner has his or her own relationship to knowledge, and this relationship is influenced by the social and cultural characteristics of the individual's life history" (p. 83). Thus, every adult learner must examine and interpret his/her individual frame of reference to become successful. Since each of them has already logged thousands of hours as learners in classrooms, these experiences, whether they are acknowledged or ignored, inform their practice as teachers.

By reflecting on the experiences of my preservice teachers and myself, I connected with teacher educators engaged in self-study of their educational practices. Self-study allows teacher educators "to maintain a focus on their teaching and on their students' learning" (Loughran, 2002), while engaging in scholarly practice. Self-study is a methodology characterized by examination of the role of the self in the research project and "the space between self and the practice engaged in” (Bullough \& Pinnegar, 2001, p. 15). According to Bullough and Pinnegar (2001), it is through written reflection and teacher conversations that we negotiate the tensions between ourselves and between our contexts, biography, and history. I found self-study to be highly compatible with Clandinin and Connelly's (1992) view of teachers as curriculum makers and Hollingsworth et al.'s (1993) view of relational knowing.

Last year, before the first practicum, I asked teacher candidates to read about the challenges faced by a new male kindergarten teacher. Following school custom, he rewarded his top student with lunch at McDonald's. During lunch, the girl became anxious and cried for her mother. After they left, his license plate was traced, and a police officer knocked on the teacher's door.

Class discussion was intense. Teacher candidates expressed strong feelings about the actions of the principal, colleagues, parents and the teacher himself. Many were disturbed by the consequences for the wellmeaning teacher.

Through our study of this case-including discussion of laws related to sexual exploitation-teacher candidates developed a heightened awareness of the prevalence of abuse, risks to teachers and students, and ways to heighten safety for all.

Still there was, unquestionably, a loss of innocence.

After class, Hannah spoke to me. While teaching at a private school, she had arranged to take a student to visit an arts summer camp. Hannah and the student drove into the city, where they stayed with Hannah's family before visiting the camp the next morning.

"Was this appropriate?” Hannah asked.

I shook my head. Well intended, yes. But not advisable. 
Hannah protested, "But this camp really turned her around. This rule to protect students would have denied her a wonderful opportunity."

I agreed, but suggested that regularly putting students in one-on-one private situations was potentially harmful. Duty of care means reducing risk to students.

A professional ethic of care involves caring deeply for students while ensuring that the highest standards of professionalism are maintained.

While education can be regarded as a "systematic course of instruction," it is also a moral activity.

Since Antiquity, "the development of character and mental powers" have both been regarded as important, with the Greeks defining curriculum as both a "course of study" and the "course of one's life". Aristotle cautioned against excessive academic and vocational specialization as rendering citizens "unfit for the pursuit and practice of goodness."

John Dewey stressed the importance of "experiences that lead to growth” intellectually and morally....

For the moral meaning to be realized, we as teachers need to embody the qualities we teach. We need to demonstrate care by developing relationships that lead to growth for our students.

Caring is about much more than being nice. Developing a professional ethic of care involves helping teachers to develop their professional practices and ethical knowledge, so that they fulfill their moral and legal duty of care.

Duty of care is laid out clearly in law. The Education Act, Section 264(1) states that educators must "teach diligently and faithfully the classes and subjects assigned” and subsequent subsections specify many other duties. In common law, the courts weigh the degree to which teachers fulfill their duty of care, using the standard of care of a prudent parent and, in some cases, the standards factor in specialized knowledge.

The Kindergarten teacher, Hannah and their principals all cared, yet they did not fully consider the professional and ethical dimensions of being teachers.

As your education law professor, I am committed to helping you understand the ethical, professional and legal dimensions of teaching. This involves more than just learning about statutes and case law. I hope that I will prompt you to construct your professional identities by reflecting on the course content in relation to your personal and professional experiences. I hope that you will draw on your moral commitment as teachers to foster classroom environments in which students' intellect and character are developed. I am committed to helping you draw on your sense of moral purpose and personal experiences to become skilled professionals and 
reflective practitioners who exercise an appropriate duty of care in crafting educative experiences that meet student needs.

The teacher's duty of care is central to education as a moral endeavour. Teachers are most likely to develop a professional ethic of caring when it is linked to their personal practical knowledge and identities.

The Ontario College of Teacher's Foundations of Professional Practice provides a solid platform on which to develop a professional ethic of caring. The Ethical Standards represent "a holistic vision of professional practice", while the Standards of Practice define a "framework for developing the knowledge, skills and values. (J. Kitchen, Lesson \#1 Developing a Professional Ethic of Caring Notes, September 2006)

Students' written reflections revealed their appreciation for these efforts to make the course engaging and meaningful. I wished that they could study cases more and listen to lectures less, yet I felt obliged to cover the curriculum in order to prepare them thoroughly for the final test and assignment. This became a major source of inner turmoil when I taught the course again in the second term, as noted in opening reflection, as I was not being true to myself or what I believed was best for my students.

This experience prompted substantive changes in the second year. Interim feedback and course evaluations were more positive than in the previous year. After reading written student feedback after the third class, I reflected:

While I have always had very positive feedback this was remarkable for so soon in the year!

The law course has often been seen as intimidating, something that has been compounded by very challenging textbooks, a huge book of legal statutes, and a content test. I want the law course to be approachable and fun, while still challenging assumptions and stimulating thinking. I was pleased that the readings were clear, the classes were relatively free of jargon, and students found the cases interesting. I really believe that it is possible to teach the law in a more engaging way while enhancing learning! Education law should model good pedagogy and contribute to the development of effective classroom practices, like any other successful course in the program.

The comment about inclusion and easy-going manner pleased me particularly. I work hard to be accessible and to build community. While the course in law does not lend itself to that as much as my methods courses have in the past, I simply try to be invitational and genuinely engaged in the learning of students. (J. Kitchen, personal communication, October 3, 2007)

By looking inward at my own identity, I was able to work frame the education law course in a way that was meaningful to me and, more importantly, to the aspiring teachers in my course.

\section{Looking Outward at the Educational Milieu}

It is critical that teacher educators look outward to the existential conditions that influence educational experiences (Clandinin \& Connelly, 2000). This involves understanding 
the immediate environment, as well as the ways in which educational contexts are shaped by dominant discourses about teaching, learning, and society (Kincheloe, 2008).

The course I was teaching reflected a positivistic worldview. There was a clear body of information about education law that needed to be disseminated to teachers. Teachers also developed skills in interpreting cases so that they would be able to understand the reasoning that underpinned legislation and legal decision-making. The assignments, however, emphasized applying education law to particular cases rather than critically examining those laws.

While I wanted my students to understand the legislation and legal thinking, I also wanted them to develop critical faculties and be aware of the power dynamics within their classes. I wanted to develop in them a sense of agency, so that they could critically examine their practices and learn to teach in a way that was respectful of students as possessors of knowledge and skills. I also wanted to model the critical, relational, and constructivist teaching approaches I believed they should be using with students in their classrooms, and which I outlined in the previous section of this paper. Simply caring for students, while necessary, is not sufficient for teaching. Teachers also need a critical understanding of the power dynamics as they play out in the contextual complexity of particular classrooms and schools.

My teacher education practices have been influenced substantively by an awareness of efforts to shift away from teacher training towards teacher education. As members of the National Academy of Education's Committee on Teacher Education reported, "teachers need a new kind of preparation-one that enables them to go beyond "covering the curriculum" to actually enable learning for students who learn in different ways" (Bransford, DarlingHammond, \& LePage, 2005, p. 2). This involves the development of adaptive expertise in order to enable teachers to make informed, critical decisions that meet the needs of students in their particular educational context (Bransford, et al., 2005). As I developed my lessons, I experienced discomfort as I negotiated the tensions between the education law course of study and my focus on developing teachers as adaptive experts.

My resolve to negotiate these tensions was strengthened after hearing a speech by Justice Paul S. Rouleau (2006) of the Court of Appeal for Ontario. In "Education in Transition: A Delicate Balance,” Justice Rouleau (2006) argued that teachers who understand ethics, professionalism and education law are better able to make sound educational decisions:

Taken independently or as a whole, these cases show a consistent approach by the courts in recognizing the professionalism, rights and, importantly, the judgment of educators... I hope that the educators among you are able to take up my challenge and operate within the legal framework in a way that respects your ultimate professional goal or purpose: to be an effective educator. Know that courts show respect for decisions made by educators....[R]ules can be either a hindrance or helpful. Don't lose your focus on educating. Be mindful of the rules but don't let them consume you. Compliance alone does not ensure excellence. (p.16)

Rouleau's words helped me maintain a focus on educating teachers as adaptive experts. It helped me to frame professionalism and law in relation to ethical teaching and good practice. I increasingly focussed on the ethical considerations that underpinned legislation, case law and effective practice. 


\section{Looking Backward at My Teacher Education Experiences}

Looking backward enables us to move forward as relational teacher educators who convey respect and empathy to preservice teachers and equip them with the reflective processes and practical skills needed to be effective teachers who direct their own professional learning. (Kitchen, 2005a, p. 29)

My constructivist and relational philosophy was strengthened by 7 years as a teacher educator, before I began teaching education law. These years at a university in which many professors applied a critical lens to educational issues, also helped me to situate pedagogical issues within a broader social context.

I worked hard to infuse an ethic of care in everything I taught, while adhering to the course of study and the assessment instruments employed, as is evident from the excerpt from my first lesson on developing a professional ethic of caring. I was already aware of the persistent concerns of teacher candidates regarding the tension between educational theory and classroom practice (e.g. Holmes Group, 1986). As a result, when I became a teacher educator, I identified myself with those who were committed to the reform of teacher education program. Working as a teacher educator heightened my awareness of the challenge of helping beginning teachers make theory-practice connections and reflect critically on their practice in order to address the needs of students in schools (Darling-Hammond \& McLaughlin, 1995).

I attempted to bridge this gap by requiring teacher candidates to employ a range of reflective practices: writing personal narratives, reflecting on critical incidents during practice teaching (Kitchen, 2008), examining case studies, and undertaking critical analysis of educational readings. These practices were designed to help them negotiate the complexity of teaching by relating theory to their complex and rich lived experiences as learners and aspiring teachers. Based on their performance and course feedback, I was confident that personal reflection and critical analysis were central to effective teacher education.

In later years, I involved my students in action research. Students were engaged by their self-directed, school-based research projects and, more importantly, gained greater awareness of educational issues and a greater sense of efficacy as teacher-researchers (Kitchen \& Stevens, 2008).

During this time, I engaged education students in the consideration of ethical and legal issues. Six hours of instructional time in an 80-hour course was devoted to education law. Often with the help of a veteran principal, I would offer warnings about the legal pitfalls inherent in teaching. Preservice teachers often were shaken by the possibility of sexual harassment charges, negligence lawsuits, and criminal assault cases. Initially, I taught law in a conventional manner, taking my guidance from former principals who were well versed in these issues. Over time, however, I grew increasingly uncomfortable with the implicit message that teachers needed to be afraid of students making false accusations. As I gained a deeper understanding of professionalism and ethics, I sought to situate the law in the broader context of professional decision-making. For example, I suggested that maintaining appropriate boundaries and decorum protected both students and teachers from harm. I began to use case studies such as the one involving the male kindergarten teacher as vehicles for probing these issues and developing responses that were respectful of students, professional, and legal. By the time I left the University of Toronto, professionalism, ethics, and law had come to play an increasingly prominent role in my teaching methods course. 
While I was open to learning from the other course instructors when I arrived at Brock University, I came to the teaching of education law with a strong and coherent sense of teacher education as constructivist and relational. This preparation gave me the strength and skill to navigate my way through the tensions of teaching a course that exemplified a different paradigm of education, while also making sure that professional standards and the law were clearly understood. My use of case studies, discussed in the previous section, reflected my orientation to teacher education. The focus on an ethic of caring, as well as efforts to link cases to the realities of the classrooms they were entering, also reflected my commitment to teaching as relational. Relational knowing (Hollingsworth, Dbydahl \& Minarik, 1993), for me, meant adopting an ethical and critical stance. In teaching about the ethical and legal reasoning that underpinned many of the key legal decisions, I highlighted the courts' expectation that teachers be caring professionals who are prudent, purposeful, mindful and relational. Teaching is about caring, not control, though teachers need to know when to exercise their judgement to ensure that schools are safe places for students.

While I was pleased with my efforts during the first year, I was convinced that I needed to change my teaching to reflect the understandings I derived from my experiences as a teacher educator. I also was committed to advocating for changes to the delivery of the education law course across the program.

\section{Looking Forward to My Future Practice}

As I negotiated the tensions of teaching education law in my first year, I imagined my future practice, and took steps to move closer to my vision of teacher education. In this section, I focus on my efforts to put into practice my understanding of education law during my second year.

In reviewing my first year after classes ended, I identified the textbook, assessment, and pedagogy as areas for improvement. The textbook was the first and largest challenge, as I found no books that were accessible, rigorous and aligned with the course curriculum. In my journal, I recorded that "not being one to complain," I began "exploring the possibility of writing a new textbook adapted to student needs" (J. Kitchen, personal communication, June 6, 2007). The chair of my department gave permission to use this resource on our campus, even if the instructors on the other campus used other resources. Over the summer, I worked with the other law instructor on my campus to develop chapters for a classroom resources and possible book. The writing went very well and, by the end of the summer, we had written more than two-thirds of the chapters in final draft form. These chapters, along with a few supplementary notes, became the course reader. In subsequent years, this resource developed into a free e-book and then a book titled, Professionalism, Law, and the Ontario Educator (Kitchen \& Dean, 2010).

In October, I asked students to provide written feedback on the course materials. Most found the writing level appropriate and the explanations of legal concepts clear. As one student wrote, "Terms are defined in basic ways then developed through case studies. This really helps clarify the terminology in a practical way." They also found the case studies "extremely helpful in understanding the reading" and providing scope for critical thinking. I was particularly pleased that one student observed, "The cases help reinforce that many different rules/laws apply to situations; it's not cut-and-dried.” Three people compared the new resources favourably with the difficult text their friends had experienced in previous years. These comments affirmed that our new readings made the course more engaging and meaningful for aspiring teachers. 
These readings reduced the amount of time I needed to spend lecturing in order for the materials to be comprehensible. Indeed, because the materials were at an appropriate instructional level, teacher candidates were able to engage more meaningfully with the text, understand the law more fully, and respond more critically and reflectively to the implications for teaching practice. In class, they were allowed more time for case studies and classroom discussion, which helped them to deepen their understanding through dialogue with peers. As a result of engaging with real stories of practice in the form of legal cases, many indicated that this was one of their most practical courses. In subsequent years, this resource was developed.

The assessment practices outlined in the course outline were another source of tension for me. Since the other instructors were content with the positivistic existing course materials assessment instruments, I decided to work within the existing structure rather than employ alternatives in my classes. I did, however, collect feedback from my students as a means of determining whether or not they were satisfied with how they were being assessed.

While some teacher candidates characterized the test as "fair and fine," others complained about ambiguous wording, invalid test construction, and inconsistency with the principles they were learning in their assessment course. In the second term, I was successful in my efforts to have the more ambiguous questions removed from the version of the test on my campus, which resulted in a much higher level of student satisfaction with a multiple-choice test worth $30 \%$ of their mark. Also, teacher candidates generally like the case study assignment at the end of the course as the scenarios "provoked discussion" and "assessed our understanding." Some found it "too lawyerly", while others viewed them as "actual situations that could affect our daily lives.” My colleague on campus expressed appreciation for the changes I made to the questions after the cases, as he received many thoughtful responses to the final question after each case asking them to reflect on how they would apply their understandings to the classroom. Many teacher candidates were concerned, however, that this was a group assignment worth 50\% of their mark.

Looking back on my two years teaching education law, I was pleased that there have been small yet significant improvements to course assessment. At the same time, I remained concerned that these assessment approaches guide me to focus more on coverage than on depth, on how the courts would interpret cases than on using the education law course as a vehicle for enhancing professional judgement and, by extension, improve classroom practice. The final evaluation in each section of the course is supposed to be similar, if not identical, so I mainly focussed on refining rather than changing assessment during these and subsequent years. Such refinements, however, can benefit all students while leaving me greater latitude to teach my course sections in a manner consistent with my pedagogical beliefs.

The ongoing feedback from students during both years affirmed that I was on the right track. The overwhelmingly positive course evaluations after the first term of the second year validated the changes I had made to pedagogy, even though I felt somewhat constrained by the assessment tools. In offering interim feedback, students praised the course as "very applicable to real life" and, as one wrote, "particularly enjoyed the classroom discussion and questioning technique. Never dull!” The only negative feedback concerned the assignments. The second term evaluations were equally positive, with fewer concerns expressed about evaluation.

As a determined yet patient change agent who wants to bring the team along with me, rather than act as a maverick, I continue to advocate for dramatic change while being willing to 
accept incremental change when necessary. As I continue to build my capital as a teacher educator and scholar, I am hopeful that the course will be reconceptualized along the lines I envisioned from the beginning. The publication of Professionalism, Law and the Ontario Educator should help in these efforts.

\section{Conclusion}

Teacher education classrooms are and will always be political spaces, as education will remain a domain in which many of society's concerns will be contested. In this paper, I took a narrative approach to examining these issues. Narrative inquiry was employed as a methodology for collecting field texts in the form of journal entries written in the midst of the process and as a means of interpreting the complexity of experience in the three-dimensional inquiry space. By taking a narrative stance and engaging in inquiry into my practices, I was able to construct meaning from experiences. By valuing my personal practical knowledge and understanding the wider education landscape, I was able to recognize the authority of my experiences. This enabled me to move forward to make changes with confidence even as I recognize that the education law milieu remains contested territory. Taking the law into my own hands as a teacher educator was a first step towards relinquishing power to beginning teachers as curriculum makers who possess the knowledge and skills to think critically and be responsive to the needs of their students and school communities. 


\section{References}

Bransford, J., Darling-Hammond, L., \& LePage, P. (2005). Introduction. In L. DarlingHammond \& J. Bransford (Eds.), Preparing teachers for a changing world: What teachers should learn and be able to do, (pp. 1-39). San Francisco: Jossey Bass.

Bullough, R.V., \& Pinnegar, S. (2001). Guidelines for quality in autobiographical forms of selfstudy research. Educational Researcher, 30(3), 13-21.

Clandinin, D. J., \& Connelly, F. M. (1992). Teacher as curriculum maker. In P. Jackson (Ed.), Handbook of research in curriculum (pp. 363-401). New York: Macmillan.

Clandinin, D.J., \& Connelly, F.M. (1995). Teachers’ professional knowledge landscapes. New York: Teachers College Press.

Clandinin, D. J., \& Connelly, F. M. (2000). Narrative inquiry: Experience and story in qualitative research. San Francisco: Jossey-Bass.

Clandinin D. J., \& Connelly, F. M. (2004). Knowledge, narrative and self-study. In J. J. Loughran, M. L. Hamilton, V. K. LaBoskey, \& T. Russell (Eds.), International handbook of self-study of teaching and teacher education practices (pp. 575-600). Dordrecht: Kluwer.

Clandinin, D. J., Huber, J., Huber, M., Murphy, S., Murray Orr, A., Pearce, M., \& Steeves, P. (2006). Composing diverse identities: Narrative inquiries into the interwoven lives of children and teachers. New York: Routledge.

Connelly, F. M., \& Clandinin, D. J. (1988). Teachers as curriculum planners. Toronto: OISE Press.

Connelly, F.M., \& Clandinin, D.J. (2000). Teacher education: A question of teacher knowledge. In J. Freeman Moir \& A. Scott (Eds.), Tomorrow's teachers: International and critical perspectives on teacher education (pp. 89-105). Christchurch, New Zealand: Canterbury Press.

Connelly, F. M., \& Clandinin, D. J. (2006). Narrative inquiry. In J. L. Green, G. Camalli, \& P. B. Elmore (Eds.), Handbook of complementary methods in education research. Washington, D.C.: American Educational Research Association.

Darling-Hammond, L., \& McLaughlin, M. W. (1995). Policies that support professional development in an era of reform. Phi Delta Kappan, 76(8), 587-604.

Dewey, J. (1938). Experience and education. New York: Collier.

Dominice, P. (2000). Learning from our lives. San Francisco: Jossey-Bass.

Downey, C. A., \& Clandinin, D. J. (2010). Narrative inquiry as reflective practice: Tensions and possibilities. In N. Lyons (Ed.). Handbook of reflection and reflective practice: Mapping a way of knowing for professional reflective inquiry, XXVII (Chapter 19). New York: Springer.

Hollingsworth, S., Dybdahl, M., \& Minarik, L. T. (1993). By chart and chance and passion: The importance of relational knowing in learning to teach. Curriculum Inquiry, 23(1), 5-35.

Holmes Group (1986). Tomorrow’s teachers. East Lansing, MI: Holmes Group.

Kincheloe, J. L. (2008). Critical pedagogy, (2nd ed.). New York: Peter Lang. 
Kitchen, J. (2005a). Conveying respect and empathy: Becoming a relational teacher educator. Studying Teacher Education, 1(2), 194-207.

Kitchen, J. (2005b). Looking backwards, moving forward: Understanding my narrative as a teacher educator. Studying Teacher Education, 1(1), 17-30.

Kitchen, J. (2008) Using written feedback to promote critical reflection: A teacher educator responds to reflective writing by preservice teachers. Excelsior, 2(2), 37-46.

Kitchen, J. (2009). Relational teacher development: A quest for meaning in the garden of teacher experience. Colgone, Germany: LAP Lambert.

Kitchen, J. \& Dean, C. (2010). Professionalism, law and the Ontario educator. St. David, Ontario: Highland Press.

Kitchen, J. \& Stevens, D. (2008). Action research in teacher education: Two teacher educators practice action research as they introduce action research to preservice teachers. Action Research 6(1), 7-28.

Kitchen, J., Smyth, E., Thompson, S., \& Lemoire, J. (2007). Promoting equity, diversity and social justice school-wide. In C. Rolheiser (Ed.), School-University partnerships: Transformation of teacher education,( pp. 18-20). Toronto, Ontario, Canada: Ontario Institute for Studies in Education of the University of Toronto.

Loughran, J. (2002). Understanding self-study of teacher education practices. In J. Loughran \& T. Russell (Eds.), Improving teacher education practices through self-study (pp. 239-248). London: RoutledgeFalmer

Phillion, J., \& Connelly. F.M. (2004). Narrative, diversity, and teacher education. Teaching and Teacher Education, 20(5), 457-471.

Pinnegar, S., \& Daynes, J. G. (2007). Locating narrative inquiry historically: Thematics in the turn to narrative. In D. J. Clandinin (Ed.), Handbook of narrative inquiry: Mapping a methodology (pp. 3-34). Thousand Oaks, CA: Sage.

Rouleau, Justice Paul S. (2006). Education in transition: A delicate balance. Invited address to Law Works, Toronto, August, 2006.

Schwab, J. J. (1970). The practical: A language for curriculum. School Review, 78, 1-23. 